\title{
Growth hormone secretion in response to glucagon stimulation test in healthy middle-aged men
}

\author{
Secreção do hormônio do crescimento em resposta ao teste de \\ estímulo com glucagon em homens saudáveis de meia-idade
}

Eduardo Micmacher', Roberto P. Assumpção', Renato G. Redorat' ${ }^{\text {, }}$ Luciana D. Spina', Ivan C. Cruz', Carla A. Silva',

Mário Vaisman', Flávia Lúcia Conceição'

\begin{abstract}
Objective: To investigate the growth hormone $(\mathrm{GH})$ response to glucagon stimulation test (GST) in a population of healthy men over 50 years old in comparison to insulin tolerance test (ITT), analysis of the spontaneous 24-hour GH profile and insulin-like growth factor 1 (IGF-I). Methods: 27 healthy men aged between 51 and 65 years were tested. Results: Using non-parametric correlation analysis, a positive correlation between GH peak after GST and mean IGF-I $(r=0.528 ; p=0.005)$ was found, as well with $\mathrm{GH}$ peak in 24-hour profile $(r=0.494 ; p=0.009)$. No correlation was found comparing GH peak after ITT with the same parameters. Ten subjects presented GH peak of less than $3.0 \mu \mathrm{g} / \mathrm{L}$ after GST, none confirmed in ITT. Conclusions: GH peak response to GST was lower than ITT, but it showed a positive correlation with mean IGF-I and also with GH peak in 24-hour profile. However, GST should not be used to differentiate organic growth hormone deficiency (GDH) from the expected decline on $\mathrm{GH}$ secretion due to aging. Arq Bras Endocrinol Metab. 2009;53(7):853-8.
\end{abstract}

Keywords

Growth hormone; somatopause; glucagon

\section{RESUMO}

Objetivo: Investigar a resposta do hormônio do crescimento (GH) ao teste de estímulo com glucagon (GST) numa população de homens saudáveis acima dos 50 anos de idade, em comparação ao teste de tolerância à insulina (ITT), além da análise do perfil de secreção espontânea de GH nas 24 horas e fator de crescimento semelhante à insulina (IGF-I) basal. Métodos: 27 homens, com idades entre 51 e 65 anos, foram submetidos aos testes. Resultados: Utilizando análise de correlação não paramétrica, encontrou-se correlação positiva entre o pico de GH pósGST e a média de IGF-I $(r=0,528 ; p=0,005)$, e também com o pico espontâneo do GH no perfil de 24 horas $(r=0,494 ; p=0,009)$. Não houve correlação do pico de GH pós-ITT com os mesmos parâmetros. Dez indivíduos apresentaram pico de GH após GST inferior a 3,0 $\mu \mathrm{g} / \mathrm{L}$, sem confirmação no ITT. Conclusões: O pico de GH pós-GST foi menor do que o obtido pós-ITT, porém demonstrou correlação positiva com a média de IGF-I e o pico de GH na secreção espontânea de 24 horas. Entretanto, o GST não demonstrou ser um bom teste para distinguir entre deficiência de hormônio de crescimento (DGH) e somatopausa. Arq Bras Endocrinol Metab. 2009;53(7):853-8.

Descritores

Hormônio do crescimento; somatopausa; glucagon

\section{INTRODUCTION}

$\mathrm{T}$ The process of aging is accompanied by an increased 1 prevalence of features of physical frailty. Signs and symptoms may include sarcopenia with reduced mus-
1 Departamento de Endocrinologia, Hospital Universitário Clementino Fraga Filho, Universidade Federal do Rio de Janeiro (UFRJ), Rio de Janeiro, RJ, Brasil
Correspondence to: Eduardo Micmacher Rua Visconde de Pirajá, 351, sala 316 - Ipanema 22010-003 - Rio de Janeiro, RJ Brasil dudamicmacher@ig.com.br

Received in Jan/22/2009 Accepted in July/28/2009 cle strength, osteopenia, reduced exercise capacity, increased visceral adiposity and poor quality of life. Adults with organic growth hormone $(\mathrm{GH})$ deficiency exhibit comparable signs and symptoms, which are significantly 
ameliorated or reversed by $\mathrm{GH}$ replacement. These findings suggest a possible association between these two groups $(1,2)$. However, we should point out that the benefits of this therapy have been shown only in patients with pituitary disease $(3,4)$.

$\mathrm{GH}$ secretion declines gradually with age. Iranmanesh and cols. (5) showed that after 21 years of age, the GH secretion rate declines in about $14 \%$ each decade of life. Some studies suggest that GH secretion may eventually cease in certain elderly patients (6). The expected decline of GH secretion with age combined with physiological changes has been named somatopause. An important question is whether this fall in GH secretion over the years is a physiological safety event of the normal aging process, or if it marks the development of a partial GH deficiency, which could possibly benefit from $\mathrm{GH}$ replacement (7).

The diagnosis of growth hormone deficiency (GHD) in adults with pituitary disease is established by a subnormal response to a stimulation test. Insulin tolerance test (ITT) is considered the test of choice, regarded as the gold standard, and GH peak $<3.0 \mu \mathrm{g} / \mathrm{L}$ defines severe GHD (8-11).

Glucagon stimulation test (GST) has been shown to be an alternative to ITT, when this test is contraindicated. It is safe, with low cost, few contraindications, and an effective test to assess both GH and ACTH secretion (12). So far, few studies have evaluated GH response to GST.

In the present study, we performed both tests, GST and ITT, in a population of healthy men above 50 years old, and, after that, we tried to establish a correlation between them and other parameters.

\section{PATIENTS AND METHODS}

Fifty volunteer participants, healthy, communitydwelling, men (50 to 69 years) were recruited through newspaper articles. All of the volunteers were evaluated through fasting blood samples for routine full blood count, liver and renal function tests, electrolytes, insulinlike growth factor 1 (IGF-I), testosterone, follicle-stimulating hormone $(\mathrm{FSH})$, luteinizing hormone $(\mathrm{LH})$, prolactin, glucose, prostate specific antigen (PSA), thyroid-stimulating hormone (TSH) and free T4.

Exclusion criteria were severe acute illness, chronic hepatic, cardiac or kidney disease, high blood pressure, diabetes mellitus, pituitary disease, cranial trauma, mental illness, history of malignancy or seizures, obe- sity (body mass index, BMI $>30 \mathrm{~kg} / \mathrm{m}^{2}$ ). We included 27 healthy men aged between 51 and 65 years (mean 58.63 years, $\mathrm{SD} \pm 4.35$ ), who underwent $\mathrm{GH}$ secretion evaluation. The $\mathrm{GH}$ secretion was evaluated through 24-hour GH spontaneous secretion, with blood samples collected hourly, GH peak response to ITT and GST, as well as IGF-I serum levels.

All of the included individuals were admitted to the hospital to be submitted to the 24-hour GH profile. Blood samples were collected hourly by an indwelling catheter inserted in an antecubital vein and kept patent by slow saline infusion. The evaluated parameters were 24-hour mean GH and spontaneous GH peak.

The ITT was performed by IV injection of regular insulin at a dose of 0.1 to $0.15 \mathrm{IU} / \mathrm{kg}$. Blood samples were drawn every 30 minutes from baseline until 120 minutes for the determination of glucose and GH levels. All patients had hypoglycemia during the test.

The GST was performed by intramuscular (IM) injection of $1 \mathrm{mg}$ of glucagon. Blood samples were drawn every 30 minutes from baseline to 180 minutes.

We decided to use the same criteria established by the guideline of Growth Hormone Research Society (GRS) (11) for GHD; a peak GH response less than $3.0 \mu \mathrm{g} / \mathrm{L}$.

The research ethics committee of Hospital Universitário Clementino Fraga Filho approved the protocol. Participants provided written informed consent.

\section{Assays}

GH analyses were performed by an immunometric assay (Immulite). The minimal detection limit was 0.01 $\mu \mathrm{g} / \mathrm{L}$ and the intra-assay coefficient of variation $(\mathrm{CV})$ was $5.3 \%$ at $1.7 \mu \mathrm{g} / \mathrm{L}$. The inter-assay $\mathrm{CV}$ was $5.7 \%$ at $3.0 \mu \mathrm{g} / \mathrm{L}$.

Serum IGF-I concentrations were determined by an IRMA Kit (Kit DSL-5600). IGF-I was extracted with ethanol. The minimal detection limit was $0.80 \mathrm{ng} / \mathrm{mL}$ and the intra-assay were $3.4 \%$ at $9.38 \mathrm{ng} / \mathrm{mL}$ and $3.7 \%$ at $255.9 \mathrm{ng} / \mathrm{mL}$.

\section{Statistical analysis}

Firstly, the Kolmogorov-Smirnov test was used to determine if the sample had homogeneous distribution. The results are expressed in mean \pm SD for variables with homogeneous distribution (Student's $t$-test) or median, minimum and maximum for variables with non homogeneous distribution (Wilcoxon or Mann-Whitney). 
Correlation analysis was realized by Pearson coefficient, for variables with homogeneous distribution, or by Spearman test, for variables with non-homogeneous distribution. P-value less than 0.05 was considered significant.

\section{RESULTS}

Table 1 presents the summary of results.

When the GH peak response was compared to ITT and glucagon, it was observed that ITT was a more powerful stimulus to GH secretion than GST ( $\mathrm{p}=$ $0.0042)$.

Mean 24-hour GH was $0.33 \pm 0.26 \mu \mathrm{g} / \mathrm{L}$ and $\mathrm{GH}$ peak was $2.41 \pm 1.82 \mu \mathrm{g} / \mathrm{L}$. Mean IGF-I was $205.5 \pm$ $68.28 \mathrm{ng} / \mathrm{mL}$. We found a positive correlation between GH peak after GST and IGF-I $(r=0.528 ; \mathrm{p}=0.005)$ (Figure 1) and also with GH peak in the 24 -hour profile $(\mathrm{r}=0.494 ; \mathrm{p}=0.009)$ (Figure 2).

There was no correlation between the GH peak response to ITT with the same parameters.

The subjects were also divided according to their response to GST. Ten subjects showed a GH concentration lower than $3.0 \mu \mathrm{g} / \mathrm{L}$ during GST, but none had the results confirmed at the ITT. Only one patient had GH peak response to ITT of less than $3.0 \mu \mathrm{g} / \mathrm{L}$.

The individuals who showed a GH peak response to GST less than $3.0 \mu \mathrm{g} / \mathrm{L}$ also showed lower IGF-I levels as well as lower mean 24-hour GH levels (Table 2). Correlation between BMI and the parameters studied was not observed.

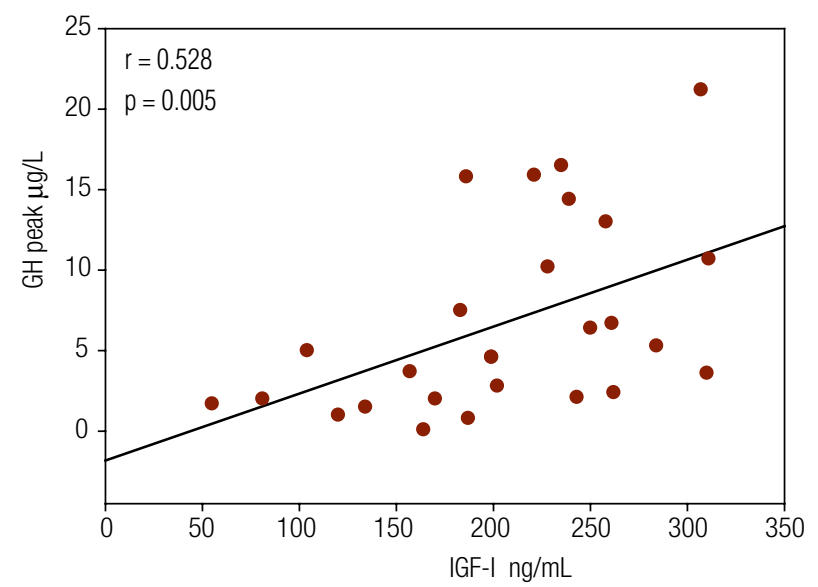

Figure 1. Correlation between GH peak after glucagon and IGF-I levels.

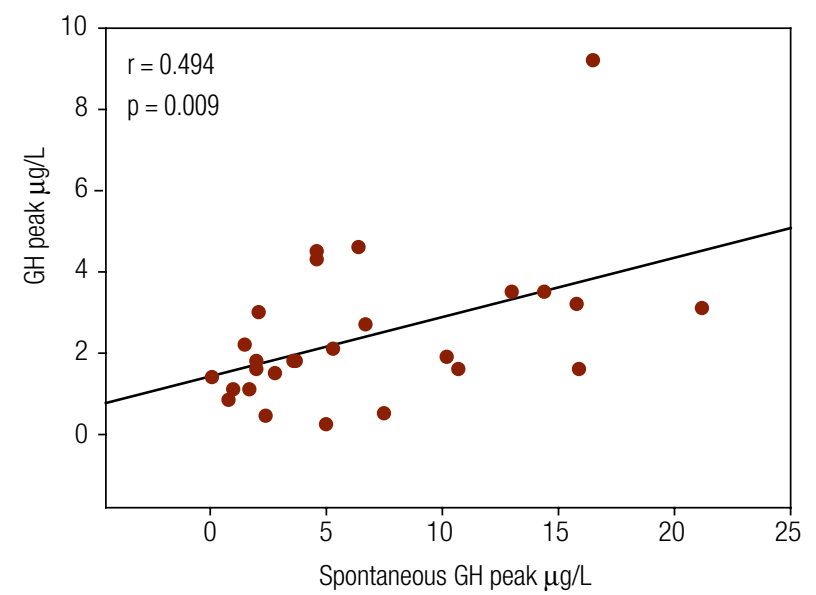

Figure 2. Correlation between GH peak after glucagon and spontaneous GH peak.

\begin{tabular}{|c|c|c|c|c|c|}
\hline & Mean & SD & Median & Minimum & Maximum \\
\hline IGF-I & 205.5 & 68.28 & 202 & 55 & 311 \\
\hline Glucagon GH peak & 6.72 & 5.87 & 4.6 & 0.09 & 21.20 \\
\hline ITT GH peak & 12.81 & 9.45 & 11.0 & 0.05 & 37.80 \\
\hline Mean 24 hours GH & 0.33 & 0.26 & 0.26 & 0.08 & 1.37 \\
\hline 24 hours GH peak & 2.41 & 1.82 & 1.80 & 0.24 & 9.2 \\
\hline
\end{tabular}

Table 2. Comparison between group 1 (GH after GST > $3 \mu / \mathrm{L}$ ) and group 2 (GH after GST $<3 \mu / \mathrm{L}$ )

\begin{tabular}{|c|c|c|c|c|c|}
\hline & \multicolumn{2}{|c|}{ Mean } & \multicolumn{2}{|c|}{ SD } & \multirow{2}{*}{ p-value } \\
\hline & Group 1 & Group 2 & Group 1 & Group 2 & \\
\hline |GF-I & 231.3 & 161.6 & 56.67 & 66.17 & 0.02 \\
\hline Glucagon GH peak & 9.71 & 15.48 & 1.64 & 0.81 & 0.000 \\
\hline ITT GH peak & 11.51 & 14.8 & 8.86 & 10.51 & 0.688 \\
\hline Mean 24 hours GH & 0.37 & 0.24 & 0.30 & 0.14 & 0.204 \\
\hline 24 hours GH peak & 2.95 & 1.49 & 2.06 & 0.72 & 0.013 \\
\hline
\end{tabular}




\section{DISCUSSION}

It is known that GH secretion undergoes clear agerelated variations that are generally reproduced by IGF-I levels. GH secretion increases gradually during childhood, peaks during puberty and then declines during adult life (6,13-15). This progressive fall in $\mathrm{GH}$ secretion, the so-called somatopause (16), is associated with somatic changes that occur as part of the aging process and include a loss of lean body mass, decreased muscle strength and increased total and visceral fat mass (14). There are, however, distinct differences between normal middle-aged subjects and GHD adults of similar age with structural hypothalamic-pituitary disease. Those with GHD have lower GH secretion and increased total body fat with a predominance of central adiposity, as compared with age-matched healthy subjects (15-19).

The clinical diagnosis of GHD in adults is still a matter of debate. Despite the long list of clinical features that constitute the adult GHD syndrome, no specific clinical parameters have been identified (19-21). As a result, the endocrinologists must rely on the pharmacological stimulation of the pituitary somatotroph to establish the diagnosis of GHD. GRS assembled a workshop in 1997 to formulate consensus guidelines for the diagnosis and treatment of adults with GHD and to ensure that patients are appropriate identified. This consensus was recently revised, but the criteria remains almost the same ones $(10,11)$. In adults, an evaluation for GHD should be considered only in patients with evidence of hypothalamic-pituitary disease, subjects who have received cranial irradiation, or patients with childhood-onset GHD. These recommendations also make it possible to distinguish between GHD and the decrease in $\mathrm{GH}$ secretion seen with aging. There is a clear difference in $\mathrm{GH}$ peak response to stimulation between healthy aging people and those with pituitary disease (15). Meanwhile, despite many aspects in somatopause that resemble GHD, clinical or laboratory diagnostic criteria have not been defined yet.

ITT has been considered the gold standard for the diagnosis of GHD. The GRS guideline recommends that severe GHD should be defined as a peak GH response of less than $3 \mu \mathrm{g} / \mathrm{L}$ during ITT (10). The study of Hoffman and cols. (22) supports the choice of this diagnostic definition. They showed a complete segregation of GH peak in response to ITT between the normal and the GHD subjects, irrespective of age or presence of adiposity. No normal subject had a GH response to an ITT $<5.0 \mu \mathrm{g} / \mathrm{L}$ and no subject with organic hypopituitarism had a response greater than 3.0 $\mu \mathrm{g} / \mathrm{L}$. In case of contraindications to ITT, alternative tests must be used with appropriate cut-offs, such as combined administration of arginine and GHRH and arginine or glucagon alone can be considered as options $(10,11)$.

The test with GHRH and arginine is the worldwide alternative choice, but it is unavailable in Brazil. The glucagon stimulation test has been shown to be safe, low cost and an effective mean of stimulating GH secretion, with few contraindications and low risk of sideeffects. Therefore, it can be considered as a suitable alternative when the ITT is contraindicated $(11,22,23)$

We have previously studied the GH response to GST in 33 patients with known pituitary disease and a control group of 25 individuals. GH peak after glucagon was significantly lower in the group of patients compared to the healthy group. ROC plot analyses of the control and GHD groups showed an area under the curve of 0.982 for GH peak response to glucagon, confirming that the glucagon test has a high power of discrimination between patients and healthy controls. The response value of $3.0 \mu \mathrm{g} / \mathrm{L}$ showed the best pair of sensitivity (97\%)/specificity ( $88 \%)$, and it was chosen as the cut-off defining GHD (24).

In this study, ten healthy individuals achieved a GH concentration lower than $3.0 \mu \mathrm{g} / \mathrm{L}$ in response to GST. By contrast, only one patient had GH peak response to ITT of less than $3.0 \mu \mathrm{g} / \mathrm{L}$. None of the individuals had two tests with criteria for the diagnosis of GHD. Our findings suggest that GST is not a good test to discriminate between healthy individuals and patients with GHD due to pituitary disease. This probably reassure the need of specific criteria to select patients to be tested for GHD $(10,11)$.

To establish the diagnostic value of a test, it is necessary to evaluate the context of its practical use or the capacity of the test to correctly distinguish between normal individuals and GHD patients (25). If we search for an alternative test to the diagnosis of GHD, it is not only necessary to define the most powerful one; the test must discriminate between normal and GHD individuals. It is known that GH secretion may be affected by poor reproducibility of response to both physiological and pharmacological tests (26-30). This may be very important in respect of qualifying patients to $\mathrm{GH}$ therapy. Current standards accept a single normal GH peak in one of the stimulation tests enough to exclude 
GHD. This assumption, however, does not take into consideration the possibility of decreased physiological GH secretion despite normal GH response to pharmacological stimulation, as it may be observed in patients with neurosecretory dysfunction of GH secretion and possibly in older healthy subjects.

We showed in this study that GH secretion in response to GST correlated to parameters of physiological GH secretion, such as mean 24-hour GH and IGF-I levels. On the other hand, there was no correlation of the GH response to ITT and the same parameters. This may reveal that $\mathrm{GH}$ response to GST resembles $\mathrm{GH}$ spontaneous secretion in healthy aging subjects. To further evaluate this matter, the subjects were divided according to their response to GST. The individuals, who showed a GH peak response to GST of less than $3.0 \mu \mathrm{g} / \mathrm{L}$, also showed lower IGF-I levels as well as lower mean 24-hour GH levels. However, it is not clear whether these individuals would benefit from GH replacement. On the other hand, it is possible to conclude that, in a population of men above 50 years old, the GST should not be used to differentiate organic GHD from the expected decline on GH secretion due to aging.

GH secretion is regulated by the coordinated action of GHRH and somatostatin, which respectively stimulate and inhibit its release from the pituitary gland. The mechanisms underlying the hyposomatotropism accompanying aging are poorly understood. Hypothalamic GHRH release and activity are reduced in aging, while there is absolute or relative hyperactivity of hypothalamic somatotropin release-inhibiting factor (SRIF) neurons (13,31-32). Iranmanesh and cols. (33) showed that somatotropin $(\mathrm{GH})$ responsiveness to exogenous GHRH drive is attenuated by increasing age, suggesting relative resistance to GHRH, lack of GH co-secretagogues and/or excessive GHRH antagonism. GH response to GHRH in elderly is clearly enhanced by neuroactive substances acting via inhibition of hypothalamic SRIF release as arginine.

The mechanism of glucagon action to stimulate GH secretion is still not clear. A relationship between a relative hypoglycemia at 90 to 150 minutes after glucagon injection and peak GH levels has been suggested. Another possible mechanism for glucagon-induced $\mathrm{GH}$ release is via noradrenergic stimulation, since it has been shown to induce noradrenaline release in healthy volunteers (34-38). The GH-releasing effect of hypoglycemia probably reflects concomitant inhibition of hypothalamic somatostatin release and activation of GHRH-secreting neurons, which might explain the higher $\mathrm{GH}$ response to ITT.

\section{CONCLUSION}

In healthy men with more than 50 years old, GH secretion in response to GST correlated to parameters of physiological spontaneous GH secretion, such as mean 24-hour GH and IGF-I levels. This may signify that GH response to GST mirrors GH spontaneous secretion in healthy aging subjects. We did not find any correlation of the GH response to ITT and the same parameters, but the ITT is notably more powerful than GST as a stimulus for the GH/IGF-I axis. Individuals with GH peak response to GST of less than $3.0 \mu \mathrm{g} / \mathrm{L}$ also showed lower IGF-I levels as well as lower mean 24-hour $\mathrm{GH}$ levels. We can also conclude that in a population of men above 50 years old, the GST should not be used to differentiate organic GDH from the expected decline on $\mathrm{GH}$ secretion due to aging.

Acknowledgment: Dr Flávia Lucia Conceição has a research grant from National Counsel of Technological and Scientific Development (CNPq).

Disclosure: This study have been supported in part by Pfizer Pharmaceutical Company. No other potential conflict of interest relevant to this article was reported.

\section{REFERENCES}

1. Salomon F, Cuneo RC, Hesp R, Sönksen PH. The effects of treatment with recombinant human growth hormone on body composition and metabolism in adults with growth hormone deficiency. N Eng J Med. 1989;321(26):1797-803.

2. Nass R, Huber RM, Klauss V, Müller OA, Schopohl J, Strasburger CJ. Effect of growth hormone $(\mathrm{hGH})$ replacement therapy on physical work capacity and cardiac and pulmonary function in patients with hGH deficiency acquired in adulthood. J Clin Endocrinol Metab. 1995;80(2):552-7.

3. Melmed S. Supplemental growth hormone in healthy adults: the endocrinologist's responsibility. Nat Clin Pract Endocrinol Metab. 2006;2:119.

4. Liu H, Bravata DM, Olkin I, Nayak S, Roberts B, Garber AM, et al. Systematic review: The safety and efficacy of growth hormone in the healthy elderly. Ann Intern Med. 2007;146(2):104-15.

5. Iranmanesh A, Lizarralde G, Veldhuis JD. Age and relative adiposity are specific negative determinants of the frequency and amplitude of growth hormone $(\mathrm{GH})$ secretory bursts and the halflife of endogenous $\mathrm{GH}$ in healthy men. J Clin Endocrinol Metab. 1991;73(5):1081-8.

6. Finkelstein JW, Roffwarg HP, Boyar RM, Kream J, Hellman L. Agerelated change in the twenty-four-hour spontaneous secretion of growth hormone. J Clin Endocrinol Metab. 1972;35 (5):665-70.

7. Savine R, Sönksen $\mathrm{PH}$. Is the somatopause an indication for growth hormone replacement? J Endocrinol Invest. 1999;22(5):142-9. 
8. Jones SL, Trainer PJ, Perry L, Wass JA, Besser GM, Grossman A. An audit of the insulin tolerance test in adult subjects in an acute investigation unit over one year. Clin Endocrinol (Oxf). 1994;41(1):123-8.

9. Hoeck HC, Vestergaard P, Jakobsen PE, Laurberg P. Test of growth hormone secretion in adults: poor reproducibility of the insulin tolerance test. Eur J Endocrinol. 1995;133(3):305-12.

10. No authors listed. Consensus guidelines for the diagnosis and treatment of adults with growth hormone deficiency: summary statement of the Growth Hormone Research Society Workshop on Adult Growth Hormone Deficiency. J Clin Endocrinol Metab. 1998;83(2):379-81.

11. Jallad RS, Bronstein MD. Growth hormone deficiency in adulthood: how to diagnose and how to treat? Arq Bras Endocrinol Metabol. 2008;52(5):861-71.

12. Leong KS, Walker AB, Martin I, Wile D, Wilding J, MacFarlane IA. An audit of 500 subcutaneous glucagon stimulation tests to assess growth hormone and ACTH secretion in patients with hypothalamic-pituitary disease. Clin Endocrinol (Oxf). 2001;54(4):463-8.

13. Brook CG, Hindmarsh PC. The somatotropic axis in puberty. Endocrinol Metab Clin North Am. 1992; 21(4):767-82.

14. Corpas E, Harman SM, Blackman MR. Human growth hormone and human aging. Endocr Rev. 1993;14(1):20-39.

15. Lamberts SW, van den Beld AW, van der Lely AJ. The endocrinology of aging. Science. 1997;278(5337):419-24.

16. Toogood AA, O'Neill PA, Shalet SM. Beyond the somatopause: growth hormone deficiency in adults over the age of 60 years. J Clin Endocrinol Metab. 1996;81(2):460-5.

17. Toogood AA, Adams JE, O'Neill PA, Shalet SM. Body composition in growth hormone deficient adults over the age of 60 years. Clin Endocrinol (Oxf). 1996;45(4):399-405.

18. Li Voon Chong JS, Groves T, Foy P, Wallymahmed ME, MacFarlane IA. Elderly people with hypothalamic-pituitary disease and untreated GH deficiency: clinical outcome, body composition, lipid profiles and quality of life after 2 years compared to controls. Clin Endocrinol (Oxf). 2002;56(2):175-81.

19. Feldt-Rasmussen U, Wilton P, Jonsson P; KIMS Study Group; KIMS International Board. Aspects of growth hormone deficiency and replacement in elderly hypopituitary adults. Growth Horm IGF Res. 2004;Suppl A:S51-8.

20. Fernholm R, Bramnert M, Hägg E, Hilding A, Baylink DJ, Mohan S, et al. Growth hormone replacement therapy improves body composition and increases bone metabolism in elderly patients with pituitary disease. J Clin Endocrinol Metab. 2000;85(11):4104-12.

21. Conceicao FL, Bojensen A, Jørgensen JO, Christiansen JS. Growth hormone therapy in adults. Front Neuroendocrinol. 2001;22(3):213-46.

22. Hoffman DM, O'Sullivan AJ, Baxter RC, Ho KK. Diagnosis of growth-hormone deficiency in adults. Lancet. 1994;343(8905):1064-8.

23. Gómez JM, Espadero RM, Escobar-Jiménez F, Hawkins F, Picó A, Herrera-Pombo JL, et al. Growth hormone release after glucagon as a reliable test of growth hormone assessment in adults. Clin Endocrinol (Oxf). 2002;56(3):329-34
24. Conceição FL, Silva AC, Costa AJL, Vaisman M. Glucagon stimulation test for the diagnosis of $\mathrm{GH}$ deficiency in adults. J Endocrinol Invest. 2003;26(11):1065-70.

25. Paula LP, Czepielewski MA. Avaliação dos métodos diagnósticos para deficiência de GH (DGH) na infância: IGFs, IGFBPs, testes de liberação, ritmo de $\mathrm{GH}$ e exames de imagem. Arq Bras Endocrinol Metab. 2008;52(5):734-44.

26. Hoeck HC, Vestergaard P, Jakobsen PE, Laurberg P. Test of growth hormone secretion in adults: poor reproducibility of the insulin tolerance test. Eur J Endocrinol. 1995;133(3):305-12.

27. Ghigo E, Bellone J, Aimaretti G, Bellone S, Loche S, Cappa M, et al. Reliability of provocative tests to assess growth hormone secretory status. Study in 472 normally growing children. J Clin Endocrinol Metab. 1996;81(9):3323-7.

28. Rosenfeld RG, Albertsson-Wikland K, Cassorla F, Frasier SD, HasegawaY, Hintz RL, et al. Diagnostic controversy: the diagnosis of childhood growth hormone deficiency revisited. J Clin Endocrinol Metab. 1995;80(5):1532-40.

29. Zadik Z, Chalew SA, Kowarski A. Assessment of growth hormone secretion in normal stature children using 24-hour integrated concentration of $\mathrm{GH}$ and pharmachological stimulation. J Clin Endocrinol Metab. 1990;71(4):932-6.

30. Pfeifer M, Kanc K, Verhovec R, Kocijancic A. Reproducibility of the insulin tolerance test (ITT) for assessment of growth hormone and cortisol secretion in normal and hypopituitary adult men. Clin Endocrinol (Oxf). 2001;54(1):17-22.

31. Pavlov EP, Harman SM, Merriam GR, Gelato MC, Blackman MR. Responses of growth hormone $(\mathrm{GH})$ and somatomedin- $\mathrm{C}$ to $\mathrm{GH}$ releasing hormone in healthy aging men. J Clin Endocrinol Metab. 1986;62(3):595-600.

32. Lang I, Schernthaner G, Pietschmann P, Kurt R, Stephenson JM, Templ $\mathrm{H}$. Effects of sex and age on growth hormone response to growth-hormone releasing hormone in healthy individuals. J Clin Endocrinol Metab. 1987;65(3):535-40.

33. Iranmanesh A, South S, Liem AY, Clemmons D, Thorner MO, Weltman $A$, et al. Unequal impact of age, percentage body fat, and serum testosterone concentrations on the somatotropic, IGF-I, and IGF-binding protein responses to a three-day intravenous growth hormone-releasing hormone pulsatile infusion in men. Eur J Endocrinol. 1998;139:59-71.

34. Cain JP, Williams GH, Dluhy RG. Glucagon stimulation of human growth hormone. J Clin Endocrinol Metab. 1970;31(2):222-4.

35. Cain JP, Williams GH, Dluhy RG. Glucagon-initiated human growth hormone release: a comparative study. Can Med Assoc J. 1972;107(7):617-22.

36. Mitchell ML, Byrne MJ, SanchezY, Sawin CT. Detection of growthhormone deficiency: the glucagon stimulation test. N Eng J Med. 1970;282(10):539-41.

37. Goodwin PM, Capildeo R, Harrop JS, Marks V, Rose FC. The metabolic and hormonal response to glucagon Part 1. Normal subjects. J Neurol Sci. 1976;27(3):373-80.

38. Orme SM, Price A, Weetman AP, Ross RJM. Comparison of the diagnostic utility of the simplified and standard i.m. glucagon stimulation test (IMGST). Clin Endocrinol (Oxf). 1998;49(6):773-8. 